\section{Stimulatory Effect of Potassium Glutamate in PCR}

\section{Alonna Knorr, Russell T. Turner, Mark E. Bolander, and Gobinda Sarkar}

Departments of Orthopedics and Biochemistry and Molecular Biology, Mayo Clinic and Foundation, Rochester, Minnesota 55905
$\mathrm{PCR}^{(1)}$ has become one of the most widely used technologies in many areas of research. PCR depends on a bacterial DNA polymerase and is quite specific and efficient in amplifying a target DNA. However, there are situations when the PCR can be suboptimal even though the specificity is not compromised. One explanation (among many) of a suboptimal PCR might be that the process is carried out in an environment foreign to a bacteria. For example, there are a number of auxiliary proteins that take part during DNA replication in a bacteria that are absent in a test tube environment. In addition, the intracellular ionic environment in bacteria, such as Escherichia coli, ${ }^{(2,3)}$ is different from that used in a standard PCR. The most relevant physiological anion in $E$. coli is glutamate, ${ }^{(3)}$ whereas chloride is the routine anion of choice in a PCR. In accordance with this observation, it has been demonstrated that replacement of potassium chloride by potassium glutamate dramatically enhances protein-DNA interactions in vitro. $^{(3)}$ The beneficial effect of such a salt requirement has been further supported by the demonstration that virtually all of the restriction enzymes tested work as well or better in a buffer containing glutamate than in a chloridecontaining buffer. ${ }^{(4)}$ Because AmpliTaq is a bacterial enzyme, we tested the effect of replacing chloride with glutamate in the buffer used for PCR. Our data demonstrate a consistent (but not dramatic) enhancement of PCR efficiency with glutamate when this enzyme is used.

PCR as described and universally practiced is best carried out at $50 \mathrm{~mm}$ $\mathrm{KCl} .{ }^{(5)}$ Therefore, we compared the efficiency of potassium glutamate (KGM) in PCR against $50 \mathrm{~mm} \mathrm{KCl}$. The effect of KGM in PCR on the amplification of two segments of 291 and 492 bp from the human interleukin-5 (IL-5) gene is presented in Figure 1. It appears that for the 291-bp segment, KGM is a better salt at all concentrations $(50-200 \mathrm{~mm}$, lanes 2-6) than $50 \mathrm{mM} \mathrm{KCl}$ (lane 1). For the 492-bp segment, however, KGM is suboptimal at some concentrations (50 and $75 \mathrm{~mm}$; lanes 8 and 9, respectively) and inhibitory at $200 \mathrm{~mm}$ (lane 12) compared with PCR of this segment at $50 \mathrm{mM} \mathrm{KCl}$. The maximum increases in the PCR amplification of these bands are seen at 100 mM KGM (lanes 4,10).

The extent of the effect of KGM in PCR was then determined in a semiquantified manner. For this, a number of segments were amplified in the presence of $\left[\alpha^{32} \mathrm{P}\right] \mathrm{dCTP}$ with $\mathrm{KCl}$ and KGM. A portion of the PCR-amplified material was electrophoresed, the DNA bands

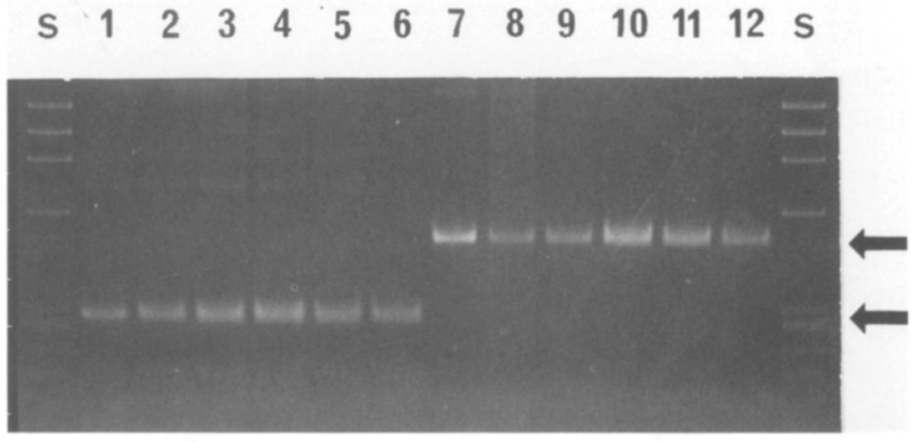

FIGURE 1 Effect of KGM in PCR. Hot-start $\mathrm{PCR}^{(6)}$ was carried out with the following sets of primers for the human IL-5 gene: primers 5'-CTG TGC AAG GGG AAG CTT GGA TCC TTA CTG TGG AAA-G-3' and 5'-CTC AAC TTT CTA TTA TCC AC-3' for the 291-bp segment and primers 5'-CTG TGC AAG GGG AAG CTT GGA TCC TTA CTG TGG AAA G-3' and 5'-CTT CAA TGA TTC TGA TAT C-3' for the 492-bp segment. Five microliters of PCR products was electrophoresed in a $2 \%$ agarose gel and stained with ethidium bromide. (Lanes 1,7) PCR of the 291- and 492-bp segments, respectively, with $50 \mathrm{mM} \mathrm{KCl}$; (lanes 2,8) PCR with $50 \mathrm{mM} \mathrm{KGM;} \mathrm{(lanes} \mathrm{3,9)} \mathrm{PCR} \mathrm{of} \mathrm{the}$ same segments with $75 \mathrm{mM} \mathrm{KGM}$; (lanes 4,10) PCR at $100 \mathrm{mM} \mathrm{KGM;} \mathrm{(lanes} \mathrm{5,11)} \mathrm{PCR} \mathrm{at} 150 \mathrm{mM}$ KGM; (lanes 6,12) PCR at $200 \mathrm{mM} \mathrm{KGM;} \mathrm{(lanes} S$ ) DNA size standards. The arrows indicate the bands of interest. PCR was carried out as describe ${ }^{(7)}$ in a total volume of $20 \mu \mathrm{l}$ and contained 10 mM Tris- $\mathrm{HCl}$ (pH 8.3), $1.5 \mathrm{~mm} \mathrm{MgCl}, 200 \mathrm{ng}$ of genomic DNA, 2 pmoles of each primer, 0.5 units of AmpliTaq, and indicated amounts of $\mathrm{KCl}$ or KGM. Hot-start PCR was achieved by maintaining the PCR mix minus Amplitaq at $94^{\circ} \mathrm{C}$ for $5 \mathrm{~min}$, followed by addition of the enzyme. The PCR profile was $1 \mathrm{~min}$ at $94^{\circ} \mathrm{C}, 2 \mathrm{~min}$ at $50^{\circ} \mathrm{C}$, and $3 \mathrm{~min}$ at $72^{\circ} \mathrm{C}$ for 30 cycles. After the last cycle, another incubation for $10 \mathrm{~min}$ at $72^{\circ} \mathrm{C}$ was allowed before using the samples. 
were detected by ethidium bromide staining, the desired DNA segments were excised, and the amount of radioactivity was measured by Cerenkov counting. The radioactive counts obtained with KGM were then expressed as percentages of the standard PCR with $\mathrm{KCl}$. This is presented in Table 1. As can be seen, there has been a significant increase in the amount of PCR-amplified product for all the segments tested. The effect ranges from $40 \%$ increase (for the 492-bp segment) to $117 \%$ increase (for the 204-bp segment). The increase in the yield is not dramatic but consistent. Most of the segments (1422-bp IL-5, 961-bp $\beta$-actin, 204-bp p53, and 338-bp p53) displayed maximal increase at $50 \mathrm{~mm} \mathrm{KGM}$ (the product yield of these segments was 50 $\mathrm{mM} \mathrm{KCl}<75$ and $100 \mathrm{mM} \mathrm{KGM}<50 \mathrm{~mm}$ KGM); however, two segments from the IL-5 gene had maximal PCR at $100 \mathrm{~mm}$ KGM. (Note that the 1422-, 961-, 204-, and 338-bp segments were not checked for PCR at $\mathrm{KCl}>50 \mathrm{~mm}$ ). This suggests that there might be a range of concentrations at which KGM will have beneficial effect in PCR; therefore, titrations with KGM should always be performed for new reactions. $K G M$ at $<50 \mathrm{~mm}$ was found to be suboptimal for most PCR. Data in Table 1 do not indicate a relationship between segment length and the stimulatory effect of KGM. The stimulatory effect of glutamate in PCR was also observed when sodium was used as the cation (data not shown).

The data presented suggest that for PCR, glutamate is a better monovalent anion than the standard concentration of chloride in PCR. The segments tested approximate the lengths commonly amplified with PCR. The molecular interactions that render glutamate more efficient than chloride in PCR are not clear at this point. However, the assumption that glutamate mimics the cellular environment more closely than chloride does $^{(3)}$ may have relevance to our finding.

The effect of glutamate on PCR efficiency as demonstrated, although not dramatic, could have important implications in at least a few contexts: (1) If the stimulatory effect of KGM in PCR is the result of a closer semblance of the cellular environment, there might be a reduced rate of misincorporation of nucleotides (this is currently under investigation). It is conceivable, however, that a higher efficiency could be attained without influencing the fidelity of PCR. A lower rate of misincorporation could also be achieved by a stimulated PCR by performing the process for fewer cycles. (2) When attempting PCR from a single molecule or a single-cell or a relatively impure template, even an incremental enhancement of PCR efficiency would be most desirable, (3) Relatively "longer" DNA segments might be amenable for amplification. Finally, it will be interesting to investigate the performance of other thermophilic polymerases with KGM in the context of PCR and PCR sequencing.

\section{ACKNOWLEDGMENTS}

We thank Carolyn Blankenship, Sara
TABLE 1 Semiquantitation of the Effect of KGM in PCR

\begin{tabular}{llc}
\hline $\begin{array}{l}\text { Segment } \\
\text { length (gene) }\end{array}$ & $\begin{array}{l}\text { Percent yield } \\
\text { with KGM }^{\mathrm{a}}\end{array}$ & $\begin{array}{l}\text { Concentration } \\
\text { of KGM (mM) }\end{array}$ \\
\hline 1422 (IL-5) & $152.33 \pm 20.5(n=3)$ & 50 \\
291 (IL-5) & $143.7 \pm 7.8(n=3)$ & 100 \\
492 (IL-5) & $140 \pm 8.7(n=3)$ & 100 \\
$961(\beta$-actin) & $175(n=1)$ & 50 \\
204 (p53) & $217(n=1)$ & 50 \\
338 (p53) & $148(n=1)$ & 50 \\
\hline
\end{tabular}

After gel electrophoresis the desired DNA bands (at $50 \mathrm{mM} \mathrm{KCl}$ ) and a band with maximum ethidium bromide intensity corresponding to KGM at $50 \mathrm{mM}$ (for 1422-, 961-, 204-, and 338-bp segments) and at $100 \mathrm{~mm}$ (for 291- and 492-bp segments) were excised and radioactivity measured by Cerenkov counting. Radioactivity in the $50 \mathrm{mM} \mathrm{KCl}$ lane for each of the segments was taken as 100. KGM was used at 50, 75, and $100 \mathrm{~mm}$ for the 1422-, 961-, 204-, and 338-bp segments. PCR was carried out as described in the legend to Fig. 1. Values for the 291- and 492-bp segments were obtained from the experiment in Fig. 1.

an base pairs.

${ }^{b}(n)$ Number of experiments.
Erickson, and Kristy Toogood for expert typing and editorial assistance. We also thank Drs. S. Sur and G. Gliech for the IL-5 primers and Dr. R. Jenkins for the p53 primers. We thank Dr. S. Kapelner for critical reading of the manuscript. The suggestions of one of the reviewers to compare sodium chloride and sodium glutamate in PCR is acknowledged. These studies were supported by $\mathrm{Na}$ tional Institutes of Health grant $\mathrm{AR}$ 41418 and the Mayo Foundation. G.S. was supported by a Mayo Thompson Fellowship.

\section{REFERENCES}

1. Mullis, K.B. and F.A. Faloona. 1987. Specific synthesis of DNA in vitro via a polymerase-catalyzed chain reaction. Methods Enzymol. 155: 335-350.

2. Richey, B., D.S. Cayley, M.C. Mossing, C. Kolka, C.F. Anderson, T.C. Farrar, and M.T. Record, Jr. 1987. Variability of the intracellular ionic environment by $E$. coli: Differences between in vitro and in vivo effects of ion concentrations on proteinDNA interactions and gene expression. $J$. Biol. Chem. 262: 7157-7164.

3. Leirmo, S., D. Harrison, D.S. Cayley, R.R. Burgess, and M.T. Record, Jr. 1987. Replacement of potassium chloride by potassium glutamate dramatically enhances protein-DNA interactions in vitro. Biochemistry 26: 2095-2101.

4. McClelland, M., J. Hanish, M. Nelson, and Yogesh Patel. 1988. KGB: A single buffer for all restriction endonucleases. Nucleic Acids Res. 16: 364.

5. Innis, M.A. and D.H. Gelfand. 1990. Optimization of PCRs. In PCR protocols: $A$ guide to methods and applications (ed. M.A. Innis, D.H. Gelfand, J.J. Sninsky, and T.J. White), pp. 3-12. Academic Press, San Diego, CA.

6. Mullis, K.B. 1991. The polymerase chain reaction in an anemic mode: How to avoid cold oligodeoxyribonuclear fusion. PCR Methods Applic. 1: 1-4.

7. Sarkar, G. and S.S. Sommer. 1989. Access to a messenger RNA sequence or its protein product is not limited by tissue or species specificity. Science 244: 331-334.

Received April 20, 1993; accepted in revised form June 25, 1993. 


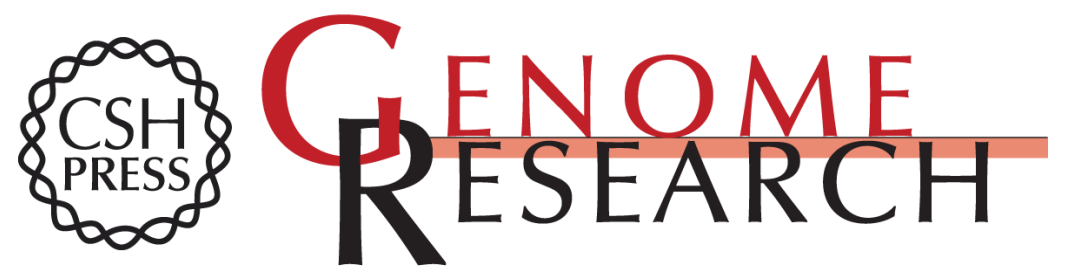

\section{Stimulatory effect of potassium glutamate in PCR.}

A Knorr, R T Turner, M E Bolander, et al.

Genome Res. 1993 3: 73-74

References This article cites 6 articles, 2 of which can be accessed free at:

http://genome.cshlp.org/content/3/1/73.full.html\#ref-list-1

\section{License}

Email Alerting Receive free email alerts when new articles cite this article - sign up in the box at the Service top right corner of the article or click here.

\section{Affordable, Accurate Sequencing.}

To subscribe to Genome Research go to: https://genome.cshlp.org/subscriptions 